\title{
Immunological Deficiency Disorders Associated with Chronic Lymphocytic Leukemia and Multiple Myeloma*
}

\author{
Lawrence Cone † and Jonathan W. Uhr \\ (From the Irvington House Institute, Department of Medicine, New York University School \\ of Medicine, and the Third and Fourth Divisions, Bellevue Hospital, \\ New York, N.Y.)
}

The observation that patients with diseases involving the lymphoreticular system may have a decreased resistance to infectious agents has stimulated numerous studies of the immunological responsiveness of such individuals. It has been shown, for example, that patients with chronic lymphocytic leukemia (CLL) and multiple myeloma (MM) have a decreased capacity to produce circulating antibody (1-9) and frequently have a low serum gamma globulin concentration $(10,11)$. The severity of these serologic abnormalities is correlated in general with increased susceptibility to bacterial infection (12). On the other hand, the delayed-type hypersensitivity skin response to several commonly encountered antigens was found to be either normal or only slightly depressed in patients with CLL $(12,13)$; other studies, however, demonstrated an impairment of the development of contact sensitivity to 2,4dinitro-1-chlorobenzene in patients with various lymphoid neoplasms $(14,15)$.

The purpose of this study was to define more precisely the nature of the immunologic defects in patients with CLL and MM and, in particular, to test the capacity for both a primary immune response and a response to antigens presumed to have been encountered before disease. Accordingly, four parameters of immunologic responsiveness were studied: primary antibody formation to bacteriophage $\phi \mathrm{X} 174$, the secondary antibody response to diphtheria toxoid, the development of primary delayed-type hypersensitivity to 2,4-

* Submitted for publication March 13, 1964; accepted July 22, 1964.

Supported by U. S. Public Health Service grant AI-01821-07.

$\dagger$ Present address: New York Medical College, New York, N. Y. dinitro-1-fluorobenzene (DNFB), and delayedtype hypersensitivity to eight commonly encountered microbial antigens. The results presented here indicate that CLL usually has a different pattern of immunologic deficiency from that observed in MM, but that in each disease, the capacity for a primary hypersensitivity response may be severely depressed, although hypersensitivity reactions to antigens previously encountered may appear intact.

\section{Methods}

\section{Paticnts}

Patients and control subjects were selected from the wards of the third and fourth medical divisions of Bellevue Hospital. The diagnosis of CLL, MM, or Waldenström's macroglobulinemia was established according to conventional clinical and laboratory criteria (16). Approximately one-half of the control group consisted of subjects who were convalescing from acute infectious diseases but who were otherwise normal; the remainder had chronic diseases not associated with known immunological abnormalities. No patients of either group had been treated with immunosuppressive drugs before or during the study.

\section{Antigens}

Bacteriophage $\phi \mathrm{X} 174$ containing $10^{11}$ plaque-forming particles per $\mathrm{ml}$ was prepared and purified as previously described (17). In this paper, the number of phage particles will refer only to the plaque formers. Two dilutions in saline, containing $10^{\mathrm{s}}$ and $10^{10}$, respectively, were sterilized by the addition of $2.5 \mu \mathrm{g}$ of streptomycin sulfate and $10 \mathrm{U}$ of penicillin $\mathrm{G}$ per $\mathrm{ml}$ and were used for immunization.

Diphtheria toxoid ${ }^{1}$ (KP 59A) containing 50 Lf per $\mathrm{ml}$, a $5 \% \mathrm{vol} / \mathrm{vol}$ solution of DNFB in acetone and a $0.01 \mathrm{M}$ solution containing equal volumes of acetone and corn oil (Mazola corn oil), and alum-precipitated mumps vaccine ${ }^{2}$ were used.

${ }^{1}$ Obtained from the Massachusetts Department of Public Health.

2 Eli Lilly and Co., Indianapolis, Ind. 
The following skin testing antigens were obtained from commercial sources : oidiomycin (Candida albicans) and trichophyton, ${ }^{3}$ histoplasmin and purified protein derivative intermediate strength (PPD), ${ }^{4}$ coccidioidin, ${ }^{5}$ mumps, ${ }^{2}$ and diphtheria toxoid (Schick control). ${ }^{1}$ Streptokinase-streptodornase (SK-SD) (commercially available as Varidase $)^{6}$ was diluted in sterile saline to give a final concentration of 750 and $500 \mathrm{U}$ per $\mathrm{ml}$, respectively.

\section{Immunization and sensitizations}

Primary antibody response. Initially, patients were immunized intramuscularly with $2.5 \times 10^{7} \phi \mathrm{X}$. To obtain higher antibody titers, the immunizing dose was increased to $2.5 \times 10^{8}$ during the study. Serum was drawn before and 2 weeks after immunization.

Secondary antibody response. $5 \mathrm{Lf}$ of fluid diphtheria toxoid was injected intramuscularly. Preimmunization sera and sera 2 weeks after immunization were obtained.

Primary delayed hypersensitivity. Two drops of $5 \%$ DNFB solution were applied to the left forearm (18). Two weeks later the patients were patch tested with a $0.01 \mathrm{M}$ solution of DNFB, which was applied on a $5-\mathrm{mm}$ piece of filter paper to the right deltoid region and held in place by an elastopatch bandage. The patch was removed 24 hours later, and the skin response read as follows: $1+=$ pink with minimal induration, $2+=$ red and moderately indurated, $3+=$ violaceous and markedly indurated, and $4+=$ vesicle formation and marked induration. None of five unsensitized patients showed a response with the patch test alone.

Delayed hypersensitivity to commonly encountered antigens. The eight skin testing antigens described above were used. Each antigen in a $0.1-\mathrm{ml}$ vol was injected intradermally into separate sites on the volar surface of the right forearm. Reactions were observed at 24 and 48 hours, and the diameter of induration was measured in millimeters. Reactions whose diameter of induration measured more than $8 \mathrm{~mm}$ were considered positive.

\section{Antibody determinations}

Antibody to $\phi \mathrm{X}$ was determined by the phage neutralization method as outlined by Adams (19). The antibody content of the serum is expressed as the rate constant of phage inactivation ( $k$ ) by that serum. To determine the quantity of rapidly sedimenting (19 S) and slowly sedimenting ( $7 \mathrm{~S}$ ) antibody, a $1: 5$ or more dilution of antiserum was incubated for 30 minutes at $37^{\circ} \mathrm{C}$ with $0.1 \mathrm{M}$ 2-mercaptoethanol (2-ME). This sulfhydryl reagent inactivates $19 \mathrm{~S}$ but not $7 \mathrm{~S}$ antibody.

Diphtheria antitoxin titers were determined by the rabbit intracutaneous test of Fraser (20). Complement

${ }^{3}$ Hollister-Stier Laboratories, Spokane, Wash.

4 Parke, Davis \& Co., Detroit, Mich.

5 Cutter Laboratories, Berkeley, Calif.

${ }^{6}$ Obtained through the courtesy of Dr. Alan Johnson. fixing antibody to mumps of pre- and postimmunization sera was also determined. ${ }^{7}$

Saline isohemagglutinins were determined by serial saline dilution with a Takatsky microtitrator. A $2 \%$ suspension of group A and B cells in saline was freshly prepared for all titrations. The titers in the control group were $1: 4$ to $1: 32$ for both anti-A and anti-B agglutinins.

\section{Serum studies}

Total serum protein was assayed by the biuret method (21) and read spectrophotometrically. Normal values were between 6.0 and $7.5 \mathrm{~g}$ per $100 \mathrm{ml}$.

Paper electrophoresis (22) was performed with a Spinco-Durrum cell apparatus using barbital buffer, $\mathrm{pH}$ 8.6 , and ionic strength 0.075 , for 14 hours at $2.5 \mathrm{ma}$. The paper strips were stained with bromphenol blue and integrated by densitometer.

Immunoelectrophoresis was performed with a SpincoDurrum cell apparatus by the micromethod described by Scheidegger (23). A barbital buffer system with $\mathrm{pH}$ 8.2 and ionic strength 0.05 was used, and electrophoresis was run for 2 hours at 4 ma per slide. Horse antihuman serum 8 was allowed to diffuse from the trough with the slides kept in a humid container overnight.

Gamma globulin levels in the sera were estimated by multiplying the percentage of normal gamma globulin obtained by paper electrophoresis by the total protein determined by the biuret method. Gamma globulin was also determined by the zinc turbidity method of Kunkel (24). Normal values for gamma globulin were 0.75 to $1.25 \mathrm{~g}$ per $100 \mathrm{ml}$ and 4 to 8 zinc turbidity $\mathrm{U}$.

\section{Results}

Control subjects. All subjects had total protein and gamma globulin serum levels in the normal range ( 6.5 to $7.5 \mathrm{~g}$ per $100 \mathrm{ml}$ ) and 13 distinct arcs including the three major immunoglobulins detected by immunoelectrophoresis (occasionally the $\gamma_{1 \mathrm{~A}}$ arc was faint). Isohemagglutinin titers ranged from $1: 4$ to $1: 32$.

The results of immunization with $\phi \mathrm{X} 174$ are presented in Table I. Preimmunization sera did not contain detectable neutralizing antibody. At 2 weeks, all subjects who received $10^{7} \phi \mathrm{X}$ had developed a serum $\mathrm{k}$ of 0.10 to 1.18 , and all those receiving $10^{9} \phi \mathrm{X}$, a serum $\mathrm{k}$ of 1.2 to 6.3 .

Table II summarizes the antibody response to diphtheria toxoid and the delayed hypersensitivity skin reactions to DNFB and the commonly encountered antigens. Considerable variation oc-

${ }^{7}$ By the New York Department of Health through the courtesy of Dr. Steve Millian.

8 Institut Pasteur, Paris, France. 
TABLE I

Primary anti- $\phi X$ response in control patients

\begin{tabular}{ccc}
\hline \hline & \multicolumn{2}{c}{ Serum $\mathrm{k}^{*}$ at 2 weeks } \\
\cline { 2 - 3 } Patient & $\begin{array}{c}\text { Immunizing } \\
\text { dose } \\
2.5 \times 10^{7} \phi \mathrm{X}\end{array}$ & $\begin{array}{c}\text { Immunizing } \\
\text { dose } \\
2.5 \times 10^{9} \phi \mathrm{X}\end{array}$ \\
\hline A.C. & 0.59 & \\
H.B. & 0.34 & \\
C.O. & 1.80 & \\
P.Z. & 0.10 & \\
H.J. & 0.36 & \\
J.G. & 0.16 & \\
R.L. & 0.18 & 2.04 \\
R.V. & & 2.77 \\
R.M. & & 3.83 \\
S.W. & & 6.34 \\
A.P. & & 1.26 \\
C.L. & & \\
\hline
\end{tabular}

* Rate constant of phage inactivation.

curred in the magnitude of the secondary response to toxoid, but all individuals tripled their preimmune antitoxin level and attained a postimmunization titer of at least $0.5 \mathrm{U}$.

All patients developed delayed hypersensitivity to DNFB, and the capacity to express the delayed hypersensitivity response to at least one of the common antigens was present in all.

Chronic lymphocytic leukemia. Serum studies of this group of patients are shown in Table III. Isohemagglutinin and gamma globulin levels were lower than in the controls. These observations, as well as the lack of correlation between the isohemagglutinin titers and gamma globulin values, have been made by previous investigators (25). By immunoelectrophoresis, the $\gamma_{1 \mathbf{M}}$ arc (19 $\mathrm{S} \gamma$-globulin) was absent in all but one patient (M.G.). The $\gamma_{1 \mathrm{~A}}$ arc was also missing
TABLE II

Delayed hypersensitivity and diphtheria antitoxin responses in 19 control patients

\begin{tabular}{|c|c|c|c|c|}
\hline \multirow[b]{2}{*}{ Patient } & \multirow{2}{*}{$\begin{array}{l}\text { Skin } \\
\text { tests } \\
\text { to } \\
\text { common } \\
\text { antigens* }\end{array}$} & \multirow[b]{2}{*}{$\begin{array}{c}\text { DNFB† } \\
\text { sensi- } \\
\text { tiza- } \\
\text { tion }\end{array}$} & \multicolumn{2}{|c|}{ Diphtheria antitoxin } \\
\hline & & & $\underset{\substack{\text { Preim- } \\
\text { tion }}}{\text { Puiza- }}$ & $\begin{array}{l}\text { Postim- } \\
\text { muniza- } \\
\text { tion }\end{array}$ \\
\hline & & & \multicolumn{2}{|c|}{$U / m l$} \\
\hline H.S. & $1 / 7$ & $1+$ & 1.0 & 10.0 \\
\hline R.M. & $4 / 7$ & $3+$ & 3.0 & 50.0 \\
\hline M.S. & $7 / 8$ & $3+$ & 0.20 & 2.5 \\
\hline B.B. & $1 / 8$ & $1+$ & 0.20 & 2.5 \\
\hline F.O. & $2 / 8$ & $1+$ & 0.50 & 150.0 \\
\hline E.H. & $3 / 8$ & $1+$ & 0.02 & 5.0 \\
\hline R.D. & $5 / 8$ & $1+$ & 0.03 & 40.0 \\
\hline I.G. & $4 / 8$ & $3+$ & 0.05 & 2.5 \\
\hline M.L. & $1 / 8$ & $1+$ & 0.50 & 40.0 \\
\hline C.J.W. & $2 / 8$ & $1+$ & 1.0 & 80.0 \\
\hline O.S. & $2 / 7$ & $2+$ & 0.30 & 50.0 \\
\hline E.G. & $5 / 8$ & $4+$ & 0.25 & 0.75 \\
\hline R.B. & $3 / 7$ & $4+$ & 0.75 & 30.0 \\
\hline G.V. & $2 / 8$ & $2+$ & 0.75 & 20.0 \\
\hline A.F. & $5 / 8$ & $2+$ & 0.25 & 30.0 \\
\hline R.G. & $4 / 7$ & $4+$ & 0.10 & 3.5 \\
\hline E.Q. & $1 / 8$ & $1+$ & 0.08 & 0.50 \\
\hline H. B. & $5 / 8$ & $3+$ & 0.25 & 50.0 \\
\hline J.D. & $3 / 8$ & $\ddagger$ & 0.08 & 1.0 \\
\hline
\end{tabular}

* Numerator represents the number of antigens that elicited reactions; denominator, number of antigens used.

$\$$ Not done.

in seven of ten, and the $\gamma_{2}$ line was frequently shortened and appeared more symmetrical than usual. In several sera, $\gamma_{2}$ appeared as double parallel lines. ${ }^{9}$

In contrast to normal individuals, patients with CLL (Table IV) either did not respond or produced only trace amounts of anti- $\phi \mathrm{X}$ antibody 2

${ }^{9}$ In two cases, an abnormal protein was detected by immunoelectrophoresis, in one (C.W.) as a macroglobulin and in the other (W.L.) as a slowly migrating $\boldsymbol{\gamma}_{2}$ paraprotein. In both instances a moderate elevation of $\gamma$-globulin was detected by the zinc turbidity method. Indeed, because of a customary hypogammaglobulinemia in patients with CLL, the elevated zinc turbidity values suggested the possibility of concomitant paraproteinemia.

TABLE III

Serum studies in patients with chronic lymphocytic leukemia (CLL)

\begin{tabular}{|c|c|c|c|c|c|c|}
\hline \multirow{3}{*}{ Patient } & \multirow{3}{*}{$\begin{array}{l}\text { Isohemag- } \\
\text { glutinin } \\
\text { titers }\end{array}$} & & & \multicolumn{3}{|c|}{ Immunoelectrophoresis } \\
\hline & & \multicolumn{2}{|c|}{$\gamma$-Globulin } & $\gamma_{1 M}$ & $\gamma_{1 \mathrm{~A}}$ & $\gamma_{2}$ \\
\hline & & $\mathrm{g} / 100 \mathrm{ml}$ & $U$ & & & \\
\hline M.S. & $1: 2$ & 0.56 & 3 & 0 & + & + \\
\hline B.P. & $1: 2$ & 0.44 & 8 & 0 & 0 & + \\
\hline M.G. & $1: 2$ & 0.69 & 5 & + & + & + \\
\hline W.B. & $1: 4$ & 0.87 & 4 & 0 & 0 & + \\
\hline R.L. & 0 & 0.38 & 2 & 0 & 0 & + \\
\hline C.W. & 0,0 & 0.35 & 20 & Abn.* & 0 & + \\
\hline I.L. & 0 & 0.23 & 1 & 0 & 0 & + \\
\hline F.E. & $1: 2$ & 0.96 & 6 & 0 & + & + \\
\hline M.K. & 0 & 0.44 & 5 & 0 & 0 & + \\
\hline W.L. & 0 & 1.20 & 23 & 0 & 0 & Abn. \\
\hline
\end{tabular}

*Abn. = abnormal. 
TABLE IV

Immunologic responses in patients with CLL

\begin{tabular}{|c|c|c|c|c|c|}
\hline \multirow[b]{2}{*}{ Patient } & \multirow{2}{*}{$\begin{array}{l}\text { Skin tests } \\
\text { to common } \\
\text { antigens* }\end{array}$} & \multirow{2}{*}{$\begin{array}{l}\text { DNFB } \\
\text { sensiti- } \\
\text { zation }\end{array}$} & \multirow[b]{2}{*}{$\underset{(\mathbf{k})}{\text { Anti- } \phi \mathrm{X} \dagger}$} & \multicolumn{2}{|c|}{ Diphtheria antitoxin } \\
\hline & & & & $\begin{array}{c}\text { Preimmu- } \\
\text { nization }\end{array}$ & $\underset{\text { nization }}{\text { Postimmu- }}$ \\
\hline MS & & & 006 & \multicolumn{2}{|c|}{$U / m l$} \\
\hline $\begin{array}{l}\text { M.S. } \\
\text { B.P. }\end{array}$ & $\stackrel{\ddagger}{1 / 8}$ & $\begin{array}{l}\ddagger \\
0\end{array}$ & $\begin{array}{r}0.06 \\
<0.01\end{array}$ & $\begin{array}{l}<0.01 \\
<0.01\end{array}$ & $\begin{array}{l}<0.01 \\
<0.01\end{array}$ \\
\hline M.G. & $3 / 8$ & 0 & $\ddagger$ & 0.02 & 0.05 \\
\hline W.B. & $1 / 8$ & 0 & 0.04 & $<0.01$ & $<0.01$ \\
\hline R.L. & $4 / 8$ & 0 & $<0.01$ & 0.05 & 0.05 \\
\hline C.W. & $0 / 8$ & 0 & $<0.01$ & 0.02 & 0.02 \\
\hline I.L. & $\ddagger$ & $\ddagger$ & 0.02 & $<0.01$ & 1.0 \\
\hline F.E. & $4^{4} / 8$ & $1+$ & 0.01 & 0.10 & 0.10 \\
\hline M.K. & $1 / 8$ & 0 & $<0.01$ & 0.01 & 0.10 \\
\hline W.L. & $1 / 8$ & 0 & $<0.01$ & 0.05 & 0.05 \\
\hline
\end{tabular}

*. Numerator represents the number of antigens that elicited reactions; denominator, number of antigens used. $\dagger$ Immunizing dose, $2.5 \times 10^{9} \phi \mathrm{X}$.

$\ddagger$ Not done.

weeks after immunization; nine of ten did not demonstrate a secondary antitoxin response, and eight of nine failed to sensitize to DNFB. Only delayed skin reactivity to commonly encountered antigens was demonstrable in all but one patient. These reactions were of similar intensity to those observed in the normal controls.

To test further the capacity for antibody formation in this group, two patients (W.B. and F.E.) with positive skin tests specific to mumps antigen were boosted with $1.0 \mathrm{ml}$ of mumps vaccine. A group of three normals with similar delayed skin reactivity to mumps antigen was boosted to serve as controls. As can be seen in Table V, the three normal patients showed an elevation in titer of four- to fivefold; no change in titer was observed in the two patients with CLL.

To determine whether delayed type hypersensitivity can be transferred to patients with CLL, two experiments involving transfer of living leukocytes were performed (26). The first utilized $2.5 \times 10^{7}$

TABLE V

Antibody titers to mumps antigen after immunization with mumps vaccine

\begin{tabular}{cccc}
\hline & & \multicolumn{2}{c}{ Antibody titer } \\
\cline { 3 - 4 } Group & Patient & $\begin{array}{c}\text { Preim- } \\
\text { munization }\end{array}$ & $\begin{array}{c}\text { Postimmu- } \\
\text { nization }\end{array}$ \\
\hline \multirow{2}{*}{ Control } & D.T. & $1: 4$ & $1: 64$ \\
& L.B. & $1: 4$ & $1: 16$ \\
& L.V. & $1: 8$ & $1: 128$ \\
CLL & W.B. & $1: 4$ & $1: 4$ \\
& F.E. & $1: 4$ & $1: 4$ \\
\hline
\end{tabular}

blood leukocytes from an SK-SD and tuberculinsensitive donor and the second, $1.3 \times 10^{7} \mathrm{lymph}$ node cells from another SK-SD and tuberculinsensitive donor. In each case, the washed cells were injected intramuscularly into a recipient with CLL who had no reactivity to these antigens. The donor cells in each experiment had an estimated viability of $75 \%$ by phase contrast microscopy. Four days after transfer the recipients were skin tested. In both cases, there was transfer of delayed hypersensitivity to both SK-SD (skin reaction measured $10 \times 10 \mathrm{~mm}$ and $12 \times$ $12 \mathrm{~mm}$, respectively) and PPD $(21 \times 18$ and $16 \times 16 \mathrm{~mm}$, respectively) to the two recipients with CLL. Histological examination of a punch biopsy from a tuberculin reaction in one recipient revealed marked infiltration with lymphoid and histiocytic cells of the perivascular and periappendiceal areas of the dermis; these features are typical of a delayed hypersensitivity reaction. In order to exclude active sensitization of the CLL recipients from the prior skin testing, one CLL patient (M.K.) was skin tested 3 times at weekly intervals with both PPD and SK-SD. His skin reactions to these antigens remained negative.

Multiple myeloma. The myeloma patients were classified according to the immunologic type paraprotein observed after immunoelectrophoresis of their sera: three had $\gamma_{1 \mathrm{~A}}$, three had micromolecular (27), and eight had $\gamma_{2}$ type paraprotein. No difference was detected among the immunologic responses of these three groups of patients. In general, the serum studies resembled those ob- 
TABLE VI

Serum studies in patients with multiple myeloma ( $M M$ )

\begin{tabular}{|c|c|c|c|c|c|c|c|}
\hline \multirow[b]{2}{*}{ Patient } & \multirow{2}{*}{$\begin{array}{l}\text { Isohemag- } \\
\text { glutinin } \\
\text { titers* }\end{array}$} & \multirow{2}{*}{$\begin{array}{c}\text { Abnormal } \\
\text { protein }\end{array}$} & \multirow{2}{*}{$\begin{array}{c}\mathrm{Zn}_{\mathrm{n}} \\
\text { durbi- } \\
\text { dity } \\
\text { units }\end{array}$} & \multirow{2}{*}{$\begin{array}{c}\text { Normal } \\
\gamma \text {-glo- } \\
\text { bulin }\end{array}$} & \multicolumn{3}{|c|}{ Immunoelectrophoresis } \\
\hline & & & & & $\gamma_{1 \mathbf{M}}$ & $\gamma_{1 \mathrm{~A}}$ & $\gamma_{2}$ \\
\hline & & $\mathrm{g} / 100 \mathrm{ml}$ & & $\mathrm{g} / 100 \mathrm{ml}$ & & & \\
\hline C.P. & $1: 4,1: 2$ & 2.25 & 8 & 1.0 & + & Abn. $\dagger$ & + \\
\hline S.H. & 0 & 6.10 & 1 & 0.44 & 0 & Abn. & + \\
\hline T.M. & $1: 8,1: 8$ & 0.45 & 10 & 0.65 & 0 & Abn. & + \\
\hline E.T. & 0 & Not detected & 5 & 0.85 & 0 & 0 & Abn. \\
\hline M.D. & $1: 2$ & 0.68 & 3 & 0.41 & 0 & + & Abn. \\
\hline F.F. & $1: 4$ & 0.83 & 23 & 0.83 & + & + & Abn. \\
\hline M. B. & $1: 8$ & 2.50 & 48 & 0.71 & 0 & + & Abn. \\
\hline D.C. & 0 & 3.64 & 34 & 0.18 & + & + & Abn. \\
\hline A.A. & 0,0 & 2.97 & 50 & 1.2 & 0 & + & Abn. \\
\hline D.K. & 0,0 & 5.00 & 48 & 0.10 & 0 & 0 & Abn. \\
\hline G.P. & 0 & 5.30 & 29 & 0.10 & 0 & 0 & Abn. \\
\hline M.T. & $1: 8,1: 4$ & 2.38 & 16 & 0.10 & 0 & 0 & Abn. \\
\hline J.B. & $1: 8,1: 16$ & 5.30 & 50 & 0.40 & 0 & 0 & Abn. \\
\hline A.S. & $1: 8,1: 4$ & 4.70 & 50 & 0.25 & 0 & 0 & Abn. \\
\hline
\end{tabular}

* 'Two figures represent anti-A and anti-B titers in individuals of blood group $\mathrm{O}$.

$\dagger$ Abn. = abnormal.

served in patients with CLL, i.e., isohemagglutinin titers and gamma globulin levels were reduced (Table VI).

As can be seen in Table VII, the anti- $\phi \mathrm{X}$ response was reduced but detectable in nine of 11 , normal in one (J.B.), and not detectable in another. A rise in antitoxin titer occurred in all 14 patients; 11 of the postimmunization titers were within the range observed in normals $(\geqq 0.5$ $U)$. Delayed hypersensitivity to at least one commonly encountered antigen was observed in all 12 patients, but six failed to develop detectable sensitization to DNFB.

Macroglobulinemia of Waldenström. One patient with this disease demonstrated a secondary response to diphtheria toxoid (increase from 0.2 to $5 \mathrm{U}$ ) but was unable to produce detectable antibody against $\phi \mathrm{X} 174$ despite three separate attempts at immunization (Table VII). A second injection of diphtheria toxoid resulted in a further increase in antitoxin titer to $10 \mathrm{U}$. He also did not develop delayed type hypersensitivity

TABLE VII

Immunologic responses in patients with $M M$

\begin{tabular}{|c|c|c|c|c|c|}
\hline \multirow[b]{2}{*}{ Patient } & \multirow{2}{*}{$\begin{array}{l}\text { Skin tests } \\
\text { to common } \\
\text { antigens* }\end{array}$} & \multirow{2}{*}{$\begin{array}{l}\text { DNFB } \\
\text { sensiti- } \\
\text { zation }\end{array}$} & \multirow[b]{2}{*}{$\underset{(\mathrm{k})}{\operatorname{Anti}-\phi X \dagger}$} & \multicolumn{2}{|c|}{ Diphtheria antitoxin } \\
\hline & & & & $\begin{array}{l}\text { Preimmu- } \\
\text { nization }\end{array}$ & $\begin{array}{l}\text { Postimmu- } \\
\text { nization }\end{array}$ \\
\hline & & & & \multicolumn{2}{|c|}{$U / m l$} \\
\hline C.P. & $1 / 7$ & $1+$ & $\ddagger$ & 1.0 & 25.0 \\
\hline S.H. & $6 / 8$ & 0 & $t$ & 0.07 & 5.0 \\
\hline T.M. & $2 / 8$ & $2+$ & $<0.01$ & 0.10 & 10.0 \\
\hline E.T. & $3 / 9 \S$ & $2+$ & $\ddagger$ & 0.03 & 0.50 \\
\hline M.D. & $4 / 8^{\circ}$ & 0 & 0.30 & 0.25 & 10.0 \\
\hline F.F. & $1 / 8$ & $1+$ & 0.56 & 0.25 & 2.5 \\
\hline M.B. & $3 / 8$ & 0 & 0.15 & 0.03 & 2.5 \\
\hline D.C. & $\neq$ & $\ddagger$ & 0.80 & $<0.01$ & 0.05 \\
\hline A.A. & $2 / 8$ & $0^{+}$ & 0.11 & $<0.01$ & 0.02 \\
\hline D. K. & $2 / 8$ & $\ddagger$ & 0.29 & 0.02 & 5.0 \\
\hline G.P. & $2 / 8$ & $0^{+}$ & 0.05 & $<0.01$ & 0.05 \\
\hline J.B. & $5 / 8$ & $2+$ & 1.4 & 0.25 & 50.0 \\
\hline M.T. & $2 / 8$ & 0 & 0.19 & 1.0 & 7.5 \\
\hline A.S. & \pm & $\ddagger$ & 0.06 & 0.02 & 1.0 \\
\hline
\end{tabular}

* Numerator represents the number of antigens that elicited reactions; denominator, number of antigens used. $\dagger$ M.D. and F.F. immunized with $2.5 \times 10^{7} \phi \mathrm{X}$; others immunized with $2.5 \times 10^{9} \phi \mathrm{X}$.

$\ddagger$ Not done.

$\S$ Markedly positive Brucella skin test. 
to $\mathrm{DNFB}$, but responded to four of the eight skin testing antigens.

\section{Discussion}

These studies confirm previous results of others (1-15) that both CLL and MM are usually associated with an immunological deficiency disorder. The studies indicate, however, that CLL usually is associated with a different pattern of immunologic deficiency than that observed in MM. In ten patients with CLL, several of whom were asymptomatic and with only minimal organ enlargement, there was profound depression of serum $\gamma$-globulin levels, primary immune response (antibody or delayed hypersensitivity), and the secondary antibody response. Only the expression of delayed-type skin reactivity to commonly encountered antigens was still consistently demonstrable. The severe impairment of antibody synthesis is well illustrated in two patients who showed marked delayed-type hypersensitivity to mumps antigen (one had a delayed-type skin reaction measuring $40 \times 60 \mathrm{~mm}$, the largest observed to mumps antigen in this study). These two patients, unlike control individuals with similar skin reactivity to mumps antigen, showed no rise in specific antibody levels after immunization with formalinized mumps vaccine. In contrast to these results, in the $M M$ group which included several moribund patients, 11 of 14 showed a secondary antibody response, and 9 of 11, the capacity to give a detectable primary response (either antibody formation or delayed-type hypersensitivity). All these patients were capable of expressing delayed-type hypersensitivity to at least one of the commonly encountered antigens.

The observed difference in the deficiency patterns associated with these two diseases may simply represent a quantitative difference of qualitatively similar defects in the immune mechanism in which immunologic functions are lost in the following order: primary immune responsiveness, secondary antibody responsiveness, and delayed hypersensitivity reactivity to previously encountered antigens. These two deficiency disorders, however, appear to be qualitatively different from those disorders described in association with Hodgkin's disease and sarcoidosis. In the latter diseases, expression of delayed-type hypersensitivity is severely suppressed or absent, but antibody formation may appear normal (2831). It is apparent, therefore, that different patterns of immunologic reactivity can be associated with different pathological entities involving the lymphoreticular system.

The present studies also indicate that the capacity for a primary response (antibody or delayed-type hypersensitivity) may be severely depressed, although expression of an already developed response (delayed-type skin reactivity to commonly encountered antigens or capacity for an anamnestic antibody response) may appear intact. Evidence for this dissociation of responsiveness is as follows:

a) Fifteen patients with CLL or MM did not develop a primary delayed type hypersensitivity response, but had skin reactions to commonly encountered antigens; no patients in these studies demonstrated the converse.

b) A similar but less striking trend is seen in the pattern of the primary and secondary antibody responses of MM patients.

c) Two patients, one with $\gamma_{1 \mathrm{~A}}$ myeloma (T.M.) and one with macroglobulinemia of Waldenström had satisfactory secondary antitoxin responses (5 and $10 \mathrm{U}$ of antitoxin, respectively), but neither patient produced detectable antibody to $\phi \mathrm{X} 174$ despite three separately spaced injections of phage. The failure to detect primary, as opposed to secondary, antibody formation in these studies is not due to differences in sensitivity of the corresponding tests. The neutralization assays for $\phi \mathrm{X}$ and for antitoxin can each detect approximately $10^{-3} \mu \mathrm{g}$ per $\mathrm{ml}$ of neutralizing antibody protein. This dissociation between primary and secondary responsiveness appears operationally analogous to that observed in experimental animals after treatment with either certain doses of ionizing radiation (32), cortisone (33), or depletion of thoracic duct lymphocytes as reported by McGregor and Gowans (34). Each of these procedures inhibits the capacity for a primary antibody response but does not similarly suppress the secondary antibody response. Our results suggest that a cell population arising from primary immunization and capable of immunologic reactivity (expression of delayed-type hypersensitivity or antibody formation) can exist without the normal accompaniment of an uncommitted population capable of responding to a new antigenic function, 
and that such immunologically committed clones of cells in contrast to uncommitted cells can remain unaffected by several different types of neoplastic processes. If this is the case, either immunological activation renders lymphoid cells more resistant to the adverse effects of neighboring neoplastic lymphoid cells or it changes the population dynamics of activated cells. Thus, in the latter event, the immune population is maintained by nonneoplastic cells in contrast to uncommitted cells that gradually are replaced by neoplastic cells. An alternative explanation is that a defect exists in a function only necessary for primary responsiveness, such as processing of antigen (35).

There are at least four possibilities that could account for immunologic deficits in CLL and MM.

a) Competition between neoplastic and immunologically competent cells for an essential factor, for example, amino acids. This is particularly unlikely for CLL, since patients with acute leukemia $(7)$ or advanced metastatic carcinoma (36) are both capable of a normal or augmented antibody response.

b) Increased rate of catabolism of serum antibody (or cellular immune factors). Passively administered $\mathrm{I}^{131}$-labeled human gamma globulin may have a shortened half-life ( 7 to 10 days) in patients with $\gamma$ - but not $\beta\left(\gamma_{1 \mathbf{A}}\right)$-type myelomas (37) ; this effect cannot by itself account for a primary antibody response that can be less than $1 \%$ of the normal.

c) Displacement of immunologically competent cells by neoplastic cells. This factor may be important in CLL but probably not in MM in which there is usually an absence of diffuse involvement of the entire lymphoid system. Furthermore, our studies support those of previous investigators showing poor correlation between the extent, duration, and severity of the disease and the immunologic deficit $(5,30)$.

d) Neoplastic involvement of cells normally involved in the immune response. By exclusion, it is suggested that in CLL, the neoplastic lymphoid cells are unable to recognize foreign antigenic determinants and initiate an immune response, even though no anatomical (38) nor histochemical (39) alterations have as yet been described in such cells. Whether or not lymphoid cells in
MM are also involved by a neoplastic process expressed as plasma cell proliferation, or whether the other factors mentioned above are sufficient to account for the observed immune deficit, is not known.

\section{Summary}

Four parameters of immunologic responsiveness were studied in ten patients with chronic lymphocytic leukemia (CLL) and 14 with multiple myeloma $(M M)$ : primary anti- $\phi X$ formation, secondary antitoxin formation, primary delayed hypersensitivity to 2,4-dinitro-1-fluorobenzene, and delayed hypersensitivity to eight antigens presumed to have been encountered before disease. The results indicate that the immunologic deficiency disorder associated with CLL is usually different from that observed in association with MM. In the former, only delayed skin reactivity to commonly encountered antigens was consistently demonstrable. In contrast, in the MM group, 11 of 14 showed a secondary antitoxin response, and 9 of 11 the capacity to give a primary response to either $\phi \mathrm{X}$ or 2,4-dinitro-1-fluorobenzene. Two patients, one with $\gamma_{1 \mathrm{~A}}$ myeloma and one with macroglobulinemia of Waldenström had normal secondary antitoxin responses but were unable to produce a detectable primary anti- $\phi \mathrm{X}$ response.

\section{Addendum}

An excellent study of immunologic responsiveness in myeloma and macroglobulinemia by Fahey, Scoggins, Utz, and Szeved, which appeared (Amer. J. Med. 1963, 35, 698) after the completion of this manuscript, was brought to our attention recently.

\section{References}

1. Moreschi, C. Ueber antigene und pyrogene Wirkung des Typhus-bacillus bei leukämischen Kranken. Z. Immun.-Forsch. 1914, 21, 410.

2. Rotky, H. Ueber die Fähigkeit von Leukamikern Antikörper zu erzeugen. Zbl. inn. Med. 1914, 35, 953.

3. Howell, K. M. The failure of antibody formation in leukemia. Arch. intern. Med. 1920, 26, 706.

4. Weinstein, G. L., and T. Fitz-Hugh, Jr. The heterophile antibody test in leukemia and leukemoid conditions. Amer. J. med. Sci. 1935, 190, 106.

5. Shaw, R. K., C. Szwed, D. R. Boggs, J. L. Fahey, E. Frei III, E. Morrison, and J. P. Utz. Infection and immunity in chronic lymphocytic leukemia. Arch. intern. Med. 1960, 106, 467. 
6. Larson, D. L., and L. J. Tomlinson. Quantitative antibody studies in man. III. Antibody response in leukemia and other malignant lymphomata. J. clin. Invest. 1953, 32, 317.

7. Larson, D. L., and L. J. Tomlinson. Quantitative antibody studies in man. II. The relation of the level of serum proteins to antibody production. J. Lab. clin. Med. 1952, 39, 129.

8. Marks, J. Antibody formation in myelomatosis. J. clin. Path. 1953, 6, 62.

9. Zinneman, H. H., and W. H. Hall. Recurrent pneumonia in multiple myeloma and some observations on immunologic response. Ann. intern. Med. 1954, 41, 1152.

10. Rundles, R. W., E. V. Coonrad, and T. Arends. Serum proteins in leukemia. Amer. J. Med. 1954, $16,842$.

11. Jim, R. T. S. Serum gamma globulin levels in chronic lymphocytic leukemia. Amer. J. med. Sci. 1957, 234, 44.

12. Miller, D. G., and D. A. Karnofsky. Immunologic factors and resistance to infection in chronic lymphatic leukemia. Amer. J. Med. 1961, 31, 748.

13. Sokal, J. E., and N. Primikirios. Delayed skin test response in Hodgkin's disease and lymphosarcoma. Effect of disease activity. Cancer (Philad.) 1961, 14, 597.

14. Epstein, W. L. Induction of allergic contact dermatitis in patients with the lymphoma-leukemia complex. J. invest. Derm. 1958, 30, 39.

15. Rostenberg, A., Jr., H. C. McCraney, and S. M. Bluefarb. Immunologic studies in the lymphoblastomas. II. The ability to develop eczematous sensitization to a simple chemical and the ability to accept passive transfer antibody. J. invest. Derm. 1956, 26, 209.

16. Cecil, R. L., and R. F. Loeb. A Textbook of Medicine. Philadelphia, W. B. Saunders Co., 1959.

17. Uhr, J. W., M. S. Finkelstein, and J. B. Baumann. Antibody formation. III. The primary and secondary antibody response to bacteriophage $\phi \mathrm{X} 174$ in guinea pigs. J. exp. Med. 1962, 115, 655.

18. Eisen, H. N., L. Orris, and S. Belman. Elicitation of delayed allergic skin reactions with haptens: the dependence of elicitation on hapten combination with protein. J. exp. Med. 1952, 95, 473.

19. Adams, M. H. Bacteriophages. New York, Interscience, 1958.

20. Fraser, D. T. The technic of a method for quantitative determination of diphtheria antitoxin by a skin test in rabbits. Trans. roy. Soc. Can., Sect. V 1931, 25, 175.

21. Kingsley, G. R. The determination of serum total protein, albumin, and globulin by the biuret reaction. J. biol. Chem. 1939, 131, 197.

22. Block, R. J., E. L. Durrum, and G. Zweig. A Manual of Paper Chromatography and Paper Electrophoresis. New York, Academic Press, 1955.
23. Scheidegger, J. J. Une micro-méthode de l'immunoélectrophorèse. Int. Arch. Allergy 1955, 7, 103.

24. Kunkel, H. J. Estimation of alterations of serum gamma globulin by a turbidimetric technique. Proc. Soc. exp. Biol. (N. Y.) 1947, 66, 217.

25. Shohl, J., E. G. Morrison, J. L. Fahey, and P. J. Schmidt. Relation of isohemagglutinin levels to gamma globulin changes in disease. J. Lab. clin. Med. 1962, 59, 753.

26. Lawrence, H. S. The cellular transfer of cutaneous hypersensitivity to tuberculin in man. Proc. Soc. exp. Biol. (N. Y.) 1949, 71, 516.

27. Heremans, J. F., and M. Th. Heremans. Studies on "abnormal" serum globulins (M-components) in myeloma, macroglobulinemia and related diseases. Immunoelectrophoresis. Acta med. scand 1961 ( suppl. 367), 27.

28. Sones, M., and H. L. Israel. Altered immunologic reactions in sarcoidosis. Ann. intern. Med. 1954, 40, 260.

29. Schier, W. W., A. Roth, G. Ostroff, and M. H. Schrift. Hodgkin's disease and immunity. Amer. J. Med. 1956, $20,94$.

30. Good, R. A., W. D. Kelly, J. Rottstein, and R. L. Vargo. Immunological deficiency diseases in Progress in Allergy. New York, S. Karger, 1962.

31. Greenwood, R., H. Smellie, M. Barr, and A. C. Cunliffe. Circulating antibodies in sarcoidosis. Brit. med. J. 1958, 1, 1388.

32. Dixon, F. J., D. W. Talmage, and P. H. Maurer. Radiosensitive and radioresistant phases in the antibody response. J. Immunol. 1952, 68, 693.

33. White, A. Effects of steroids on aspects of the metabolism and functions of the lymphocyte: a hypothesis of the cellular mechanisms in antibody formation and related immune phenomena. Ann. N. Y. Acad. Sci. 1958, 73, 79.

34. McGregor, D. D., and J. L. Gowans. The antibody response of rats depleted of lymphocytes by chronic drainage from the thoracic duct. J. exp. Med. 1963, 117, 303.

35. Fishman, M. Antibody formation in vitro. J. exp. Med. 1961, 114, 837.

36. Balch, H. H. Relation of nutritional deficiency in man to antibody production. J. Immunol. 1950, 64, 397.

37. Lippincott, S. W., S. Korman, C. Fong, E. Stickley, W. Wolins, and W. L. Hughes. Turnover of labeled normal gamma globulin in multiple lyeloma. J. clin. Invest. 1960, 39, 565.

38. Bessis, M. Studies in electron microscopy of blood cells. Blood 1950, 5, 1083.

39. Braunstein, H., D. G. Freiman, W. Thomas, Jr., and E. A. Gall. A histochemical study of the enzymatic activity of lymph nodes. III. Granulomatous and primary neoplastic conditions of lymphoid tissue. Cancer (Philad.) 1962, 15, 139. 